\title{
First report of Quinqueloculina Carinatastriata (Wiesner, 1923) (foraminifera) along the french atlantic coast (Marennes-Oléron bay and ile de Ré)
}

\author{
Vincent M. P. Bouchet ${ }^{1,2,4}$, Jean-Pierre Debenay ${ }^{2,3}$ and Pierre-Guy Sauriau ${ }^{1}$
}

1 CRELA (UMR 6217 CNRS-IFREMER-ULR), Place du séminaire, B.P. 5, 17137 L'Houmeau, France 2 BIAF (UPRES EA2644), Université d'Angers, 2 Bd Lavoisier, 49045 Angers Cedex, France

3 IRD, UR 055 Paléotropique, Centre de Nouméa, BP A5, 98848 Nouméa Cedex, New Caledonia

4 Correspondence author. E-mail: Vincent.Bouchet@ifremer.fr

\begin{abstract}
:
Large populations of the living benthic foraminifera Quinqueloculina carinatastriata (Wiesner, 1923) are reported for the first time from intertidal mudflats of the French Atlantic coast (Marennes-Oléron Bay and lle de Ré). Maximum abundance of living specimens was recorded in early autumn. The species was previously described from the Adriatic and Tyrrhenian Seas (central Mediterranean Sea) and reported from the Eastern Mediterranean and Red Seas, as well as tropical and subtropical regions. A survey of available literature to trace records of the species in muddy shallow habitats along the western coasts of Europe and Africa reveals that the species is unrecorded from the Western Mediterranean Sea and is unknown in the eastern Atlantic Ocean from the Ivory Coast to Denmark, including the British Isles. This supports the hypothesis that the species has been accidentally introduced outside its natural range as a probable result of mariculture trade and/or shipping activities. This is the first report of a successful introduction of a non-indigenous benthic foraminifera to the Atlantic coast of Europe.
\end{abstract}




\section{INTRODUCTION}

The foraminifera Quinqueloculina carinatastriata (Wiesner, 1923) has been reported primarily in the Adriatic Sea (Wiesner, 1923), and then in the Mediterranean Sea from Eastern Mediterranean to the Tyrrhenian and Adriatic Seas (e.g. Daniels, 1970; Cimerman and Langer, 1991; Avşar and others, 2001; Debenay and others, 2005; Bernasconi and others, 2006). The species has also been reported in tropical and subtropical areas such as Xisha Island, China (Zheng, 1979), the Indian River, Florida (Buzas and Severin, 1982) and the Papuan Lagoon, New Guinea (Haig, 1988). Belonging to the difficult group of striate miliolids, the species might have been included in other striate or costate miliolids by some authors, and confusion with similar-looking Q. tasmanica Albani, 1978 is possible. Nevertheless, none of the striate species previously reported from the European Atlantic coast has characteristics similar enough to these species to lead to an incorrect identification (e.g., Le Campion, 1968; Rosset-Moulinier, 1972; Redois and Debenay, 1996; Debenay and others, 2001; Cearreta and others, 2002a; Cearreta and others, 2002b; Armynot du Chatelet and others, 2005; Ruiz and others, 2005; Morvan and others, 2006).

The objectives of the present study were twofold: (1) to elucidate the taxonomic status of Quinqueloculina populations recently sampled on intertidal mudflats of the Marennes-Oléron Bay and Ile de Ré (French Atlantic coast) and (2) to evaluate the hypothesis that the species has been accidentally introduced into these sheltered bays outside its native range. The latter was evaluated through a literature synopsis to trace records of the species in similar muddy habitats along the Mediterranean, Western African and Western European coasts. This biogeographic approach was combined with a review of introduction pathways, particularly those that are known to be involved in the successful transportation of non-indigenous species into the Marennes-Oléron Bay. 


\section{ENVIRONMENTAL SETTING}

The Marennes-Oléron Bay and Ile de Ré are located on the French Atlantic coast north of the Gironde estuary (Fig. 1). The Marennes-Oléron Bay is a semi-enclosed bay with large intertidal areas dominated by muddy sediments (Sauriau and others, 1989) and devoted to the cultivation of the Pacific oyster Crassostrea gigas (Thunberg) (Goulletquer and Héral, 1997). The bay is Europe's largest production area for the Pacific oyster, which was introduced during the 1970's after the Portuguese oyster C. angulata (Lamark) was decimated by a viral disease (Grizel, 1989). Oyster culture also extend to the northern parts of Ile de Ré, mainly in sheltered habitats characterized by muddy and muddy-sand sediments (Faure, 1969).

The nearest major seaport handling international cargo is the Port de La Rochelle-Pallice, which is located north of the Marennes-Oléron Bay and east of the Ile de Ré (Fig. 1). From 1993 to 1995, Masson (2003) classified the ballast of cargo vessels arriving in the port based on the last port of call (i.e., probable source of ballast waters and/or sediments). Although most of the vessels originated from the northeast Atlantic coasts, a few were from other areas: $7 \%$ originated from the Mediterranean and Black Seas and 2\% were from subtropical and tropical regions, including the Atlantic and Indian Oceans and the Red Sea (Masson, 2003; Masson, communication, 2006). Nowadays, the Port de La Rochelle-Pallice is the largest in Europe for the importation of tropical wood from northwest Africa, South America, the Caribbean, Ile de La Réunion and Indonesia. Fertilizers are also imported and come mainly from the Arabian Peninsula (Subdivision Port Hydrographie et Dragage, 2006).

\section{MATERIAL AND METHODS}

The foraminifera samples of this study were collected as part of a benthic survey performed to describe changes in benthic foraminiferal assemblages under the influence of oyster cultures. Thirty-two samples were collected at four intertidal sites in March, June, 
September and December 2004. Sampling sites were located at Bellevue (B), Les Traires (LT) and Daire (D) from the Marennes-Oléron Bay and Rivedoux (R) from Ile de Ré (Fig. 1). At each sampling site, samples were taken from both oyster parks (off- and on-bottom culture) and oyster-free areas (control).

At the time of sampling, water salinity was measured at each station. In order to determine grain size distribution at each sampling site, sediment samples were collected in March 2004. Using a pseudo-replication method (Hurlbert, 1984), the uppermost layer of the sediment (5 mm) was scraped off and kept in 70\% alcohol mixed with seawater for foraminiferal study.

Sediment analyses were conducted using a laser granulometer (Malvern Instruments; grain size from $0-800 \mu \mathrm{m})$. The weight values of each size were expressed as percentages. The sediments were classified according to their sand-mud (mud $=$ silt + clay) ratio (Folk, 1954).

In the laboratory, "living" foraminifera were identified following rose Bengal staining (Walton, 1952). After drying of the sediment, foraminifera were concentrated by flotation in carbon tetrachloride. More than 150 dead foraminifera and 150 living (stained) foraminifera were collected and identified in each sample and the abundance of each species (number of stained foraminifera in $50 \mathrm{~cm}^{3}$ of sediment) was determined.

Specimens of Quinqueloculina carinatastriata were collected for detailed taxonomic studies. Scanning electron microphotography was performed on living (stained) specimens of Q. carinatastriata with a FEI Quanta 200F scanning electron microscope after samples had been coated with gold.

\section{SYSTEMATIC POSITION}

The classification follows Loeblich and Tappan (1987) 
Order FORAMINIFERIDA Eichwald, 1830

Suborder MILIOLINA Delage and Hérouard, 1896

Family HAUERINIDAE Schwager, 1876

Genus Quinqueloculina d'Orbigny 1826

Quinqueloculina carinatastriata (Wiesner, 1923)

1923 Adelosina milletti Wiesner var. carinata-striata Wiesner in Wiesner, p. 76-77,

P1. 14, figs. 190, 191.

1982 Quinqueloculina carinatastriata (Wiesner) in Buzas and Severin, Pl. 2, figs. 11-

13.

1987 Quinqueloculina poeyana carinata Albani in Baccaert, P1. 47, figs. 4a, 4b.

1988 Quinqueloculina carinatastriata (Wiesner) in Haig, Pl. 5, figs. 9-10.

1991 Adelosina carinata-striata Wiesner in Cimerman and Langer, Pl. 20, figs. 1-4.

1993 Cycloforina (?) carinata (Albani) in Hottinger, Halicz and Reiss, P1. 32, figs. 1-

9.

2005 Adelosina carinata striata Wiesner in Debenay, Millet and Angelidis, P1. 1, fig.

15.

\section{DIAGNOSTIC AND TAXONOMIC REMARKS}

Description. Specimens collected from both the Marennes-Oléron Bay and Ile de Ré have chambers arranged in indistinctly quinqueloculine patterns with 3-5 chambers visible from the exterior (Pl. 1). About 12 costae run obliquely along the chambers and may unite peripherally. A carina may run longitudinally on the last chamber from the neck to the aboral end of the test. The aperture is terminal, generally at the end of a short neck, bordered by a small peristomal rim, with a small tooth, somewhat inflated, hardly bifid at the tip. Great variability occurs in ornamentation, and in the size of the rim and of the carina. 
Remarks. Our specimens show some similarities with the Atlantic striate species Quinqueloculina poeyana d'Orbigny, 1839. However, the neotype of this species, illustrated by le Calvez (1977), has parallel costae, without a carina, and the aperture is almost flush with the surface and is provided with a bifid tooth. Thus, our specimens cannot be placed into $Q$. poeyana. They closely resemble two species that are somewhat confused in the literature: $Q$. carinatastriata (Wiesner, 1923) and Q. tasmanica Albani, 1978 (TABLE 1).

The two species have common characteristics, mainly longitudinal costae meeting at the periphery where they form a carina, and an aperture produced on a neck, generally with a simple tooth sometimes somewhat inflated at its tip. Their main differences are the lateral compression and the longer neck of Qinqueloculina tasmanica. However, Haig (written communication, 2007) considers that variations in the neck length may be considered as intraspecific. The same author Haig (1988) placed similar morphotypes to Q. tasmanica into Q. carinatastriata (P1. 5, Figs. 6-8), even if he considers that they have the long neck of typical Q. tasmanica (Haig, written communication, 2007). The specimens from MarennesOléron Bay and Ile de Ré closely resemble the specimens from the Great Barrier Reef assigned to $Q$. poeyana carinata (now renamed $Q$. tasmanica; Albani, 1978) by Baccaert (1987, Pl. 47, Figs. 4a, 4b), and to the specimens from the Red Sea figured by Hottinger and others (1993, P1. 32, Figs. 1-9) as Cycloforina (?) carinata (Albani). They are also similar to the specimens from the Papuan Lagoon, New Guinea, assigned to Q. carinatastriata by Haig (1988, P1. 5, Figs. 9, 10), to Adelosina carinatastriata figured by Cimerman and Langer (1991, P1. 20, Figs. 1-4) from the Adriatic Sea, and to A. carinata striata figured by Debenay and others (2005, P1. 1, Fig. 15) from the Aegean Sea.

Owing to their inflated chambers and relatively short neck, we chose to attribute our specimens to Quinqueloculina carinatastriata (Wiesner, 1923). 


\section{RESULTS}

Salinity and grain size distribution were reported in Table 2. Salinity ranged from $30.2 \mathrm{psu}$ at Daire to 32.5 psu at Rivedoux and study site sediments were composed of more than $80 \%$ $\operatorname{mud}(<63 \mu \mathrm{m})$

Quinqueloculina carinatastriata was found in fourteen of a total of thirty-two samples from the Marennes-Oléron Bay and Ile de Ré (Fig. 1). Living individuals were collected only in September and December in all the sampling sites (Fig. 2). The highest abundance of about 2500 living individuals of $Q$. carinatastriata in $50 \mathrm{~cm}^{3}$ of sediment was recorded in September in the oyster-free zone of Les Traires and constituted up to $54 \%$ of the living foraminiferal assemblage at this site. Individuals were free living in the sediment.

The main living foraminiferal species associated with Quinqueloculina carinatastriata, ordered by decreasing abundance, were as follows: Ammonia tepida (Cushman), Cribroelphidium excavatum (Terquem), Haynesina germanica (Ehrenberg), Brizalina striatula (Cushman), Hopkinsina pacifica Cushman and Q. seminula (Linné) at all sites, Cribroelphidium gunteri (Cole) at all sites but Daire, Stainforthia fusiformis (Williamson) at all sites but Bellevue, Textularia earlandi Parker at Les Traires and Rivedoux, Cornuspira involvens (Reuss) at Les Traires, and Eggerelloides scabrus (Williamson) at Rivedoux.

\section{DISCUSSION}

Along the northeast Atlantic coast, the only striate or costate species with a morphology related to Quinqueloculina carinatastriata is Q. jugosa Cushman, 1944 (e.g., Redois and Debenay, 1996; Cearreta and others, 2002a; Cearreta and others, 2002b; Ruiz and others, 2004; Ruiz and others, 2005; Debenay and others, 2006; Morvan and others, 2006). 
Nevertheless, the two species can be easily distinguished based on the almost parallel costae without a carina, both of which characterize $Q$. jugosa but not $Q$. carinatastriata. Among the species that have some morphological similarity with $Q$. carinatastriata, Le Campion (1970) reported one specimen of Q. costata Terquem, 1878 (renamed Q. tenagos Parker, 1962), in the Bassin d'Arcachon, south of the study area, but he did not provide an illustration of this single specimen, which might belong to $Q$. jugosa. One of the specimens illustrated by Terquem (1878, Pl. 6, Fig. 3) is closely related to Q. poeyana, but the other ones are quite different, and this species is rather confused (Le Calvez and Le Calvez, 1958).

According to previous studies (Fig. 3), Quinqueloculina carinatastriata has been reported from the Red Sea (Hottinger and others, 1993), the Eastern Mediterranean Sea along the Egyptian and Turkish coastlines (Avşar and others, 2001; Bernasconi and others, 2006), the Aegean Sea (Debenay and others, 2005) and in several localities within the Adriatic and Tyrrhenian Seas (Wiesner, 1923; Daniels, 1970; Cimerman and Langer, 1991). However, our literature survey failed to detect any records of the species in coastal lagoons of the Western Mediterranean Sea or in intertidal or shallow subtidal habitats of the Atlantic coasts of Western Africa and northwestern Europe (Fig. 3). The current disjunct geographical distribution of $Q$. carinatastriata with only one Atlantic record of a well-established population, which is located far from the natural pathway between the Atlantic Ocean and the Mediterranean Sea (Strait of Gibraltar), supports the conclusion that the species is not native to the Atlantic coast and has been introduced into the Marennes-Oléron Bay and Ile de Ré.

Goulletquer and others (2002) stated that the Marennes-Oléron Bay and coastal areas in the vicinity of La Rochelle are particularly exposed to the introduction of non-indigenous species (NIS): at least 40 NIS have been reported in Marennes-Oléron Bay and adjacent areas from a total of 104 NIS recorded along the English Channel and French Atlantic coast since the beginning of the 19th century. However, the list provided by Goulletquer and others 
(2002) does not include any non-indigenous foraminiferal species, neither do synopses of Leppäkoski and others (2002) or Streftaris and others (2005) for NIS across European waters. Similarly, the current 1032 records of the Delivering Alien Invasive Species Inventories for Europe (DAISIE) database (Gollasch, 2006) do not include any non-indigenous foraminiferal species (Gollasch and Goulletquer, written communication, 2006). At a worldwide scale, a few non-indigenous foraminiferal species with naturalized populations in recipient regions have been reported to date (e.g., McGann and others, 2000), and just one non-indigenous foraminiferal species is already known from the North Sea (Hayward and others, 2004). As these North Sea specimens came from populations suspected of having been introduced by transoceanic ships (McGann, written communication, 2006), this would constitute the first case of a successful introduction of a non-indigenous foraminifer into European waters. Consequently, the present results on Quinqueloculina carinatastriata would constitute the second described case of a successful introduction of non-indigenous foraminifera into European waters, and the first described case on the European Atlantic coast.

Apart from species deliberately introduced for aquaculture purposes, the main vectors of NIS introductions are ballast waters and/or ballast sediments, ship hull fouling and accidental releases linked to shellfish activities (Carlton, 1992; Gollasch, 2002; Leppäkoski and others, 2002; Gollasch, 2006). For instance, among the documented NIS introductions into the Marennes-Oléron Bay and adjacent areas, 14 species have been introduced via ballast waters and/or ship hull fouling and 16 as accidental releases linked to mariculture (Goulletquer and others, 2002). Ballast waters discharged from ships are recognized as a primary vector for global transport of non-indigenous aquatic species (Smith and others, 1999; Gollasch, 2002). Among transported invertebrate taxa in ballast waters, foraminiferal species are not rare (Gollasch and others, 2002) and have been recorded on numerous occasions all over the world (McGann and others, 2000; see the review of Drake and others, 2001). Similarly, Gollash 
(2002) reported at least nine examples, including five NIS, of benthic foraminifera transported in ballast tank sediments of ships visiting German ports. Because Quinqueloculina carinatastriata is reported from tropical and subtropical areas, it could not be definitively excluded that living specimens of $Q$. carinatastriata might have been transported by transoceanic ships. Shellfish industries have also led to numerous human-mediated dispersal of NIS (Carlton, 1992; Goulletquer and others, 2002). Easy transportation of sediments and associated living organisms along with molluscs for aquaculture has been reviewed by Wolff and Reise (2002). Transfers of commercial molluscs, such as the European flat oyster Ostrea edulis Linné, the Pacific oyster Crassostrea gigas and the Manila clam Ruditapes philippinarum (Adams and Reeve), have been plentiful between the Mediterranean and Atlantic shellfish areas (Sauriau, 1991; Goulletquer and Héral, 1997). Particular attention should be drawn to the development of the Manila clam industry in Adriatic lagoons since the mid 1980's because Italy has become the leading European producer of clams in the last decade (Flassch and Leborgne, 1992; Breber, 2002). As a number of accompanying NIS have been attributed to the Manila clam trade (Gofas and Zenetos, 2003), a convincing argument has been recently given by Simon-Bouhet and others (2006) using mitochondrial gene sequences from the gastropod Cyclope neritea Linné, one of the NIS species already reported from the Marennes-Oléron Bay and Ile de Ré by Goulletquer and others (2002). This species has extending its range northward along the French Atlantic coast since the 1980's (Sauriau, 1991), and mitochondrial analyses have revealed that it was the result of multiple introductions from its Mediterranean native range, particularly from the Eastern Adriatic Sea. All sampled populations of $C$. neritea from Marennes-Oléron, Ile de Ré and Brittany appeared to have been mixed with haplotypes recorded from Eastern Adriatic lagoon populations (Simon-Bouhet and others, 2006), as the result of Manila clams exchanges. Since $Q$. carinatastriata populations of this study have been sampled from intertidal areas where $C$. 
neritea has been previously recorded (see details in Sauriau, 1991; Bouchet and Sauriau, unpublished data), it is likely to have been introduced in sediments associated with shellfish imported from the Adriatic Sea.

Our specimens have been found in mud facies, as reported by Wiesner (1923) and Haig (1988) in their studies in the Istrian Peninsula and in the Papuan Lagoon, respectively. The large population of Quinqueloculina carinatastriata (2500 living individuals in $50 \mathrm{~cm}^{3}$ of sediment) shows that this species has found favorable conditions for its growth and reproduction along the French Atlantic coast. Maximum abundance of living individuals in September suggests a massive reproduction during summer, when water and superficial sediments at low tide are the warmest, reflecting the origin of the species from warmer climates, which seems to corroborate Mediterranean and/or tropical-subtropical origin. The same timing of reproduction has been reported for other macrofaunal NIS originating from warmer regions and introduced into the Marennes-Oléron Bay and Ile de Ré in similar intertidal habitats, such as the Mediterranean gastropod Cyclope neritea (Sauriau, 1991; Simon-Bouhet and others, 2006). Newly introduced populations of $C$. neritea have also benefited from the warming of coastal waters within the Marennes-Oléron Bay during the last two decades (Sauriau, 1991; Soletchnik and others, 1998). Finally, the process of acclimatization and naturalization of NIS from warmer regions into temperate recipient regions with active shellfish activities and shipping ports is likely to continue in the present era of climate warming.

\section{ACKNOWLEDGMENTS}

The authors thank D. W. Haig and an anonymous reviewer for constructive discussions about the taxonomic position of our specimens. The paper also benefited from the helpful comments of the JFR's editor C. A. Brunner and the associate-editor K. Finger. The authors 
are particularly grateful to $\mathrm{M}$. McGann for firsthand information about non-indigenous foraminiferal species at sites worldwide, and to M. Langer for helpful information about the Mediterranean distribution of $Q$. carinatastriata and about the foraminiferal assemblages in the Western Mediterranean Sea. The authors also thank P. Goulletquer and S. Gollasch for helpful information about the EU-funded DAISIE database (Delivering Alien Invasive Species Inventories for Europe: http://www.europe-aliens.org/). We are also grateful to L. Joassard, F. Mornet, D. Leguay and P. Pineau for their assistance during fieldwork, M. Bordes from the Centre Commun d'Analyses for the SEM microphotographs, M. Lebourdec from the Port of La Rochelle-Pallice Authority (Direction Départementale de l'Equipement) for information on commercial ship traffic and Y. Descatoire for graphics work. This study was funded by “Angers Agglomération” by a Ph.D. studentship given to V.M.P.B. 


\section{REFERENCES}

AlBANI, A. D., 1974, New benthonic foraminiferida from Australian waters: Journal of Foraminiferal Research, v. 4, p. 33 - 39.

------, 1978, Recent foraminifera of an estuarine environment in Broken Bay, New South Wales: Australian Journal of Marine and Freshwater Research, v. 29, p. 355-398.

------, FAVero, V. M., and Serandrei Barbero, R., 1998, Distribution of sediment and benthic foraminifera in the Gulf of Venice, Italy: Estuarine, Coastal and Shelf Science, v. 46 , p. 251-265.

Alve, E., and Murray, J. W., 2001, Temporal variability in vertical distributions of live (stained) intertidal foraminifera, southern England: Journal of Foraminiferal Research, v. 31, p. 12-24.

Armynot du Chatelet, E., Debenay, J.-P., Degre, D., and Sauriau, P.-G., 2005, Utilisation des foraminifères benthiques comme indicateurs de paléo-niveaux marins? Etude du cas de l'anse de l'Aiguillon: Comptes Rendus Palevol, v. 4, p. 209-223.

Avşar, N., Meriç, E., and Ergin, M., 2001, Foraminiferal content of the benthogenic sediments in the Iskenderun Bay: Yerbilimleri, Ankara, v. 24, p. 97-112.

BACCAERT, J., 1987, Distribution patterns and taxonomy of benthic foraminifera in the Lizard Island reef complex, Northern Great Barrier Reef, Australia: Unpublished Ph.D. Thesis, University of Liège, $800 \mathrm{p}$.

Bernasconi, M. P., Melis, R. M., and Stanley, J-D., 2006, Benthic biofacies to interpret Holocene environmental changes and human impact in Alexandria's Eastern Harbour, Egypt: The Holocene, v. 16, p. 1163-1176.

Breber, P., 2002, Introduction and acclimatisation of the Pacific carpet clam, Tapes philippinarum, to Italian waters, in Leppäkoski, E., Gollasch, S, and others (eds.), 
Invasive Aquatic Species of Europe: Distributions, Impacts and Management: Kluwer Scientific, Dordrecht, p. 120-126.

BuzAs, M. A., and SeVErIN, K. P., 1982, Distribution and systematics of Foraminifera in the Indian River, Florida: Smithsonian Contributions to the Marine Sciences, v. 16, p. 173.

CARLtON, J. T., 1992, Introduced marine and estuarine mollusks of North America: an endof-the-20th-century perspective: Journal of Shellfish Research, v. 11, p. 489-505.

Cearreta, A., 1988, Population dynamics of benthic foraminifera in the Santoña Estuary, Spain: Benthos'86, Revue de Paléobiologie, Special Publication No. 2, p. 721-724.

------, Alday, M., Freitas, M. C., Andrade, C., and Cruces, A., 2002a, Modern foraminiferal record of alternating open and restricted environmental conditions in the Santo André lagoon, SW Portugal: Hydrobiologia, v. 475/476, p. 21-27.

------, ------, Ulibarri, I., Yusta, I., Croudace, I. W., and Cundy, A. B., 2002b, Recent salt marsh development and natural regeneration of reclaimed areas in the Plentzia Estuary, N. Spain: Estuarine, Coastal and Shelf Science, v. 54, p. 863-886.

------, Irabien, M. J., Leorri, E., Yusta, I., Croudace, I. W., and Cundy, A. B., 2000, Recent anthropogenic impacts on the Bilbao Estuary, northern Spain: geochemical and microfaunal evidence: Estuarine, Coastal and Shelf Science, v. 50, p. 571-592.

Cimerman, F., and Langer, M. R., 1991, Mediterranean Foraminifera: Slovenian Academy of Natural Sciences, and the Scientific Research Center of the Slovenian Academy of Sciences and Arts, Ljubljana, 118 p.

CocCIONI, R., 2000, Benthic foraminifera as bioindicators of heavy metal pollution. A case study from the Goro Lagoon (Italy), in Martin, R. E. (ed.), Environmental Micropaleontology, Topics in Geobiology, v. 15: Kluwer Academic/Plenum Publishers, New York, p. 71-103. 
Cushman, J. A., 1944, Foraminifera from the shallow water of the New England coast: Cushman Laboratory for Foraminiferal Research, Special Publication No. 12, p. 1-37.

DANIELS, C. H., Von., 1970, Quantitative ökologische Analyse der zeitlichen und rämlichen Verteilung rezenter Foraminiferen im Limski kanal bei Rovinj (nördliche Adria): Göttinger Arbeiten zur Geologlie und Paläontologie, Göttingen, v. 8, p. 1-109.

Debenay, J.-P., Arfi, R., and Konate, S., 1987, Foraminifères récents des milieux paraliques des côtes d'Afrique de l'Ouest: Géologie Méditerranéenne, Marseille, v. 14, p. 5-13.

------, MiLlet, B., and Angelidis, M. O., 2005, Relationships between foraminiferal assemblages and hydrodynamics in the Gulf of Kalloni, Greece: Journal of Foraminiferal Research, v. 35, p. 327-343.

------, Bicchi, E., Goubert, E., and Armynot du ChÂtelet, E., 2006, Spatio-temporal distribution of benthic foraminifera in relation to estuarine dynamics (Vie estuary, Vendée, W France): Estuarine, Coastal and Shelf Science, v. 67, p. 181-197.

------, Tsakiridis, E., Soulard, R., and Grossel, H., 2001, Factors determining the distribution of foraminiferal assemblages in Port Joinville Harbor (Ile d'Yeu, France): the influence of pollution: Marine Micropaleontology, v. 43, p. 75-118.

Diz, P., FrANCÉS, G., and Rosòn, G., 2006, Effects of contrasting upwelling-downwelling on benthic foraminiferal distribution in the Rìa de Vigo (NW Spain): Journal of Marine Systems, v. 60, p. 1-18.

D'OrbignY, A., 1839. Foraminifères, in Sagra, R., de la (ed), Histoire physique, politique et naturelle de l'île de Cuba: A. Bertrand, Paris, p. 224.

Drake, L. A., ChOI, K.-H., RuIz, G. M., and DobBs, F. C., 2001, Global redistribution of bacterioplankton and virioplankton communities: Biological Invasions, v. 3, p. 193199. 
Duchemin, G., Jorissen, F. J., Redois, F., and Debenay, J.-P., 2005, Foraminiferal microhabitats in a high marsh: Consequences for reconstructing past sea levels: Palaeogeography, Palaeoclimatology, Palaeoecology, v. 226, p. 167-185.

FAURE, G., 1969, Bionomie et écologie de la macrofaune des substrats meubles de la côte charentaise: Tethys, v. 1, p. 751-778.

Favry, A., Guelorget, O., Debenay, J.-P., and Perthuisot, J. P., 1998, Distribution des peuplements de foraminifères actuels dans une lagune méditerranéenne: l'étang du Prévost: Vie et Milieu, v. 48, p. 41-53.

Flassch, J. P., and Leborgne, Y., 1992, Introduction in Europe, from 1972 to 1980, of the Japanese Manila Clam (Tapes philippinarum) and the effects on aquaculture production and natural settlement: ICES Marine Science Symposia, v. 194, p. 92-96.

FOLK, R. L., 1954, The distinction between grain size and mineral composition in sedimentary-rock nomenclature: Journal of Geology, v. 62, p. 344-359.

Gehrels, W. R., and Newman, S. W. G., 2004, Salt-marsh foraminifera in Ho Nugt, western Denmark, and their use as sea-level indicators: Danish Journal of Geography, v. 104, p. $97-106$.

Gofas, S., and ZenETos, A., 2003, Exotic molluscs in the Mediterranean basin: current status and perspectives, in Gibson, R. N., and Atkinson, R. J. A. (eds.) Oceanography and Marine Biology--An Annual Review, v. 41, p. 237-277.

GOLLASCH, S., 2002, The importance of ship hull fouling as a vector of species introductions into the North Sea: Biofouling, v. 18, p. 105-121.

------, 2006, Overview on introduced aquatic species in European navigational and adjacent waters: Helgoland Marine Research, v. 60, p. 84-89.

------, MacDonald, E., Belson, S., Botnen, H., Christensen, J. T., Hamer, J. P., Houvenaghel, G., Jelmert, A., Lucas, I., Masson, D., McCollin, T., Olenin, S., 
Persson, A., Wallentinus, I., Wetsteyn, L. P. M. J., and Wittling, T., 2002, Life in ballast tanks, in Leppäkoski, E., Gollasch, S, and others (eds.), Invasive Aquatic Species of Europe. Distribution, Impacts and Management: Kluwer Academic Publishers, Dordrecht, p. 217-231.

GoulletQuer, P., and HÉral, M., 1997, Marine molluscan production trends in France: from fisheries to aquaculture, in MacKenzie, C. L., Burrell, V. G. and others (eds.), The History, Present Condition, and Future of the Molluscan Fisheries of North America and Europe: NOAA Technical Report NMFS 129, Department of Commerce, Seattle, p. 137-164.

------, Bachelet, G., SAuriau, P.-G., and NoËL, P., 2002, Open Atlantic coast of Europe--a century of introduced species into French waters, in Leppäkoski, E., Gollasch, S., and others (eds.), Invasive Aquatic Species of Europe. Distribution, Impacts and Management: Kluwer Academic Publishers, Dordrecht, p. 276-290.

GrIZEL, H., 1989, Pathologie des mollusques bivalves et protection des cheptels coquilliers, in Troadec, J.-P. (ed.), L'Homme et les Ressources Halieutiques: Ifremer-Centre de Brest, Plouzané, p. 389-418.

Guelorget, O., Favry, A., Debenay, J.-P., and Perthuisot, J. P., 1999, Les écosystèmes paraliques: distribution des peuplements de foraminifères actuels dans les étangs de Diana et d'Urbino (Corse): Vie et Milieu, v. 49, p. 51-68.

-----, ------, Reynaud Louali, L., and Perthuisot, J. P., 2000a, Les peuplements de foraminifères benthiques actuels dans l'organisation biogéologique de la lagune de Nador (Maroc): Vie et Milieu, v. 50, p. 45-58.

------, ------, Moreno, F., Reynaud Louali, L., and Perthuisot, J. P., 2000b, Etude des peuplements de foraminifères de trois systèmes paraliques albanais: Vie et Milieu, v. 50, p. $177-189$. 
HAIG, D. W., 1988, Distribution of miliolid foraminifera in marine sediment around Motupore Island, Papua New Guinea: Science in New Guinea, v. 14, p. 54-94.

Hayward, B. W., Holzmann, M., Grenfell, H. R., Pawlowski, J., and Triggs, C. M., 2004, Morphological distinction of molecular types in Ammonia--towards a taxonomic revision of the world's most commonly misidentified foraminifera: Marine Micropaleontology, v. 50, p. 237-271.

HofKer, J., 1977, The foraminifera of Dutch tidal flats and salt marshes: Netherlands Journal of Sea Research, v. 11, p. 223-296.

Horton, B. P., and Edwards, R. J., 2006, Quantifying Holocene sea-level change using intertidal foraminifera: lessons from the British Isles: Cushman Foundation for Foraminiferal Research, Special Publication No. 40, 97 p.

Hottinger, L., Halicz, E., and Reiss, Z., 1993, Recent foraminiferida from the Gulf of Aqaba, Red Sea: Razred za naravoslovne vede, classis IV: Historia Naturalis, Slovenska akademija, Ljubljana, 179 p.

HuRlbert, S. J., 1984, Pseudoreplication and the design of ecological experiments: Ecological Monographs, v. 54, p. 187-211.

LANGER, M. R., 1988, Recent epiphytic foraminifera from Vulcano (Mediterranean Sea): Benthos'86, Revue de Paléobiologie, Special Publication No. 2, p. 827-832.

------, and SCHMIDT-SinNS, J., 2006, The 100 most common foraminifera from the Bay of Fetovaia, Elba Island (Mediterranean Sea): Institut für Paläontologie, Universität Bonn, Bonn, $37 \mathrm{p}$.

------, FrICK, H., and SILK, M. T., 1998, Photophile and sciaphile foraminiferal assemblages from marine plant communities of Lavezzi Islands (Corsica, Mediterranean Sea): Revue de Paléobiologie, v. 17, p. 525-530. 
LE CALVEZ, Y., 1977, Révision des foraminifères de la collection d'Orbigny, II: Les foraminifères de l'île de Cuba: Cahiers de Micropaléontologie, v. 1, p. 82-83.

Le Calvez, J., and Le Calvez, Y., 1958, Répartition des foraminifères dans la baie de Villefranche. 1-Miliolidae: Annales de l'Institut Océanographique Monaco, v. 35, p. $159-234$.

Le CAmpion, J., 1968, Foraminifères des principaux biotopes du Bassin d'Arcachon et du proche océan (inventaire faunistique): Bulletin du Centre d'Etudes et de Recherche Scientifique, Biarritz, v. 7, p. 207-391.

------, 1970, Contribution à l'étude des foraminifères du Bassin d'Arcachon et du proche océan: Bulletin de l'Institut Géologique du Bassin d'Aquitaine, v. 8, p. 3-98.

LeppäKoski, E., Gollasch, S., and Olenin, S., 2002, Invasive aquatic species of Europe. Distribution, impacts and management: Kluwer Academic Publishers, Dordrecht/Boston/London, 583 p.

Loeblich, A. R., JR., and TAPPAN, H., 1987, Foraminiferal Genera and Their Classification: Van Nostrand Reinhold Company, New York, 2 v., 970 p.

MASSON, D., 2003, Les eaux de ballast des navires, sources d'introduction d'organismes nuisibles: La Revue Maritime, v. 464, p. 224-229.

Mateu, G. M., 1970, Contribucion al conocimiento de los foraminiferos actuales: estudio sistematico y bioecologico de los foraminiferos viventes de los littorales de Cataluna y Baleares: Trabajos del Instituto Espanol de Oceanografia, v. 38, p. 1-84.

McGann, M., Sloan, D., and Cohen, A. N., 2000, Invasion by a Japanese marine microorganism in western North America: Hydrobiologia, v. 421, p. 25-30.

Morvan, J., Debenay, J.-P., Jorissen, F., Redois, F., Bénéteau, E., Delplancke, M., and AmATo, A.-S., 2006, Patchiness and life cycle of intertidal foraminifera: implication 
for environmental and paleoenvironmental interpretation: Marine Micropaleontology, v. 61, p. $131-154$.

Moufl-El-Houari, L., Ambroise, D., and MAthieu, M., 1999, Distribution des foraminifères benthiques actuels sur la marge continentale algéroise (baie de BouIsmaïl): Revue de Micropaléontologie, v. 42, p. 315-327.

MOULINIER, M., 1967, Répartition des foraminifères benthiques dans les sédiments de la baie de Seine entre le Cotentin et le méridien de Ouistreham: Cahiers Océanographiques, v. 19, p. 477-494.

PARKER, F. L., 1962, Quinqueloculina tenagos, new name for Quinqueloculina rhodiensis Parker, preoccupied: Contributions from the Cushman Foundation for Foraminiferal Research, v. 13, p. 110.

Redois, F., and Debenay, J.-P., 1996, Influence du confinement sur la répartition des foraminifères benthiques. Exemple de l'estran d'une ria mésotidale de Bretagne méridionale: Revue de Paléobiologie, v. 15, p. 243-260.

Rosset-Moulinier, M., 1972, Etude des foraminifères des côtes nord et ouest de Bretagne: Travaux du laboratoire de géologie, Ecole Normale Supérieure, Paris, 225 p.

Ruiz, F., Gonzalez-Regalado, M. L., Borrego, J., Abad, M., and Pendon, J. G., 2004, Ostracoda and foraminifera as short-term tracers of environmental changes in very polluted areas: the Odiel estuary (SW Spain): Environmental Pollution, v. 129, p. 4961.

------, ------, Pendon, J. G., AbAd, M., Olias, M., and MuÑoz, J. M., 2005, Correlation between foraminifera and sedimentary environments in recent estuaries of Southwestern Spain: applications to Holocene reconstructions: Quaternary International, v. 140-141, p. 21-36. 
SAMIR, A. M., 2000, The response of benthic foraminifera and ostracods to various pollution sources: a study from two lagoons in Egypt: Journal of Foraminiferal Research, v. 30, p. 83-98.

SAuriaU, P.-G., 1991, Spread of Cyclope neritea (Mollusca: Gastropoda) along the northeastern Atlantic coasts in relation to oyster culture and to climatic fluctuations: Marine Biology, v. 109, p. 299-309.

------, Mouret, M., and Rince, J.-P., 1989, Organisation trophique de la malacofaune benthique non cultivée du bassin ostréicole de Marennes-Oléron: Oceanologica Acta, v. 12, p. 193-204.

Sgarella, F., and Moncharmont Zei, M., 1993, Benthic foraminifera of the Gulf of Naples (Italy): systematics and autoecology: Bollettino della Societa Paleonyologica Italiana, v. 32, p. $145-264$.

------, BARRA, D., and ImprotA, A., 1983, The benthic foraminifers of the Gulf of Policastro (southern Tyrrhenian Sea, Italy): Bollettino della Societa dei Naturalisti in Napoli, v. 92, p. 67-114.

Simon-Bouhet, B., Garcia-Meunier, P., and Viard, F., 2006, Multiple introductions promote range expansion of the mollusc Cyclope neritea (Nassariidae) in France: evidence from mitochondrial sequence data: Molecular Ecology, v. 15, p. 1699-1711.

Smith, L. D., Wonham, M. J., McCann, L. D., Ruiz, G. M., Hines, A. H., and Carlton, J. T., 1999, Invasion pressure to a ballast-flooded estuary and an assessment of inoculant survival: Biological Invasions, v. 1, p. 67-87.

Soletchnik, P., Faury, N., Razet, D., and Goulletquer, P., 1998, Hydrobiology of the Marennes-Oléron bay. Seasonal indices and analysis of trends from 1978 to 1995: Hydrobiologia, v. 386, p. 131-146. 
Streftaris, N., Zenetos, A., and Papathanassiou, E., 2005, Globalisation in marine ecosystems: the story of non-indigenous marine species across European seas: Oceanography and Marine Biology: an Annual Review, v. 43, p. 419-453.

Subdivision Port Hydrographie et Dragage, 2006, La Rochelle-Pallice port de commerce trafic 2005: Service Maritime de la Direction Départementale de l'Equipement de la Charente-Maritime Report, 56 p.

Terquem, O., 1878, Les foraminifères et les entomostracés-ostracodes du Pliocène Supérieur de l'île de Rhodes: Mémoires de la Société Géologique de France, v. 3, p. 1-135.

VaniceK, V., Juracic, M., Bajraktarecic, Z., and Cosovic, V., 2000, Benthic foraminiferal assemblages in a restricted environment--an example from the Mljet Lakes (Adriatic Sea, Croatia): Geologia Croatica, v. 53, p. 269-279.

VENEC-PeYRE, M.-T., 1984, Ecologie des foraminifères en Méditerranée nord-occidentale: étude de la distribution des foraminifères vivant dans la baie de Banyuls-sur-Mer, in Bizon, J. J. and Burollet, P. F. (eds.), Ecologie des micro-organismes en Méditerranée occidentale 'ECOMED': Association française des techniciens du pétrole, Paris, p. 6080.

Walton, W. R., 1952, Techniques for recognition of living foraminifera: Contributions from the Cushman Foundation for Foraminiferal Research, v. 3, p. 56-60.

WIESNER, H., 1923, Die miliolideen der östlichen Adria: Privately printed, Prag-Bubenec, 113 p.

WolfF, W. J., and REISE, K., 2002, Oyster imports as a vector for the introduction of alien species into northern and western European coastal waters, in Leppäkoski, E., Gollasch, S., and others (eds.), Invasive Aquatic Species of Europe. Distribution, Impacts and Management: Kluwer Academic Publishers, Dordrecht, p. 193-205. 
YASSINI, I., and JONES, B. G., 1995, Foraminiferida and Ostracoda from Estuarine and Shelf Environments on the Southeastern Coast of Australia: University of Wollongong Press, Wollongong, $484 \mathrm{p}$.

ZHENG, S., 1979, The Recent foraminifera of the Xisha Islands, Guangdong Province, China: Studia Marina Sinica, v. 15, p. 101-232. 
Figure captions

FIgURE 1. Map of the Marennes-Oléron Bay and Ile de Ré with location of the sampling sites at Bellevue (B), Les Traires (LT), Daire (D) and Rivedoux (R).

FIGURE 2. Abundance of living (stained) Quinqueloculina carinatastriata (number of stained individuals in $50 \mathrm{~cm}^{3}$ of sediment) at Bellevue, Les Traires, Daire and Rivedoux on March, June, December and September 2004 (black: oyster park; white: control).

FIGURE 3. Location of previous studies on foraminiferal faunas in similar habitats where Quinqueloculina carinatastriata was mentioned (filled square) or non-mentioned (filled circle). MENTIONED: A present study; B Bay of Piran (Cimerman and Langer, 1991); C Istrian Peninsula (Wiesner, 1923; Daniels, 1970); D Naxos Island (Langer, written communication, 2007); E Gulf of Kalloni (Debenay and others, 2005); F Iskenderum Bay (Avşar and others, 2001); G Gulf of Aqaba (Hottinger and others, 1993); H Alexandria Harbour (Bernasconi and others, 2006). Unillustrated specimen: ? Gulf of Policastro (Sgarella and others, 1983). NoT MENTIONED: 1 Kentra Bay, 2 Training Bay, 3 Alnmouth Marsh, 4 Nith estuary, 5 Cowpen Marsh, 6 Roudsea Marsh, 7 Welwick Marsh, 8 Brancaster Marsh, and 9 Thornham Marsh (Horton and Edwards, 2006); 10 Hamble estuary (Alve and Murray, 2001); 11 Keyhaven Marsh, 12 Bury Farm, 13 Arne Peninsula, 14 Newton Bay, and 15 Rusheen Bay (Horton and Edwards, 2006); 16 Ho Bugt (Gehrels and Newman, 2004); 17 Dutch tidal flats and salt marshes (Hofker, 1977); 18 Authie estuary (Debenay, communication, 2007); 19 Bay of Seine (Moulinier, 1967); 20 Northern Brittany, and 21 Western Brittany (Rosset-Moulinier, 1972); 22 Southern Brittany (Redois and Debenay, 1996); 23 Gulf of Morbihan (Duchemin and others, 2005); 24 Bay of Bourgneuf (Morvan and others, 2006); 25 Ile d'Yeu (Debenay and others, 2001); 26 Vie estuary (Debenay and others, 2006); 27 Aiguillon cove (Armynot du Chatelet and others, 2005); 28 Arcachon Bay (Le Campion, 1968); 29 Bilbao estuary (Cearreta and others, 2000); 30 Plentzia estuary (Cearreta and others, 2002b); 31 Santoña estuary (Cearreta, 1988); 32 Rìa de Vigo (Diz and others, 2006); 33 Santo André lagoon (Cearreta and others, 2002a); 34 Odiel estuary (Ruiz and others, 2004); 35 Huelva coast (Ruiz and others, 2005); 36 Balearic Islands, and 37 Cataluna coasts (Mateu, 1970); 38 Bay of Banyuls (Vénec-Peyré, 1984); 39 
Prévost Lagoon (Favry and others, 1998); 40 Bay of Villefranche (Le Calvez and Le Calvez, 1958); 41 Elba Island (Langer and Schmidt-Sinns, 2006); 42 Diana and d'Urbino lagoons (Guelorget and others, 1999); 43 Lavezzi Islands (Langer and others, 1998); 44 Gulf of Naples (Sgarella and Moncharmont Zei, 1993); 45 Vulcano (Langer, 1988); 46 Milazzo (Langer, written communication, 2007); 47 Goro Lagoon (Coccioni, 2000); 48 Gulf of Venice (Albani and others, 1998); 49 Mljet Lakes (Vanicek and others, 2000); 50 Karavasta, Narta and Butrinti (Guelorget and others, 2000b); 51 Manzalah and Edku lagoons (Samir, 2000); 52 Tunisia coasts (Langer, written communication, 2007); 53 Bou Ismaïl Bay (Moufli-El-Houari and others, 1999); 54 Nador lagoon (Guelorget and others, 2000a); 55 Cap Timiris, 56 Senegalian estuaries and lagoon, 57 Kaloum peninsula, and 58 Ebrie lagoon (Debenay and others, 1987). 
Figure 1

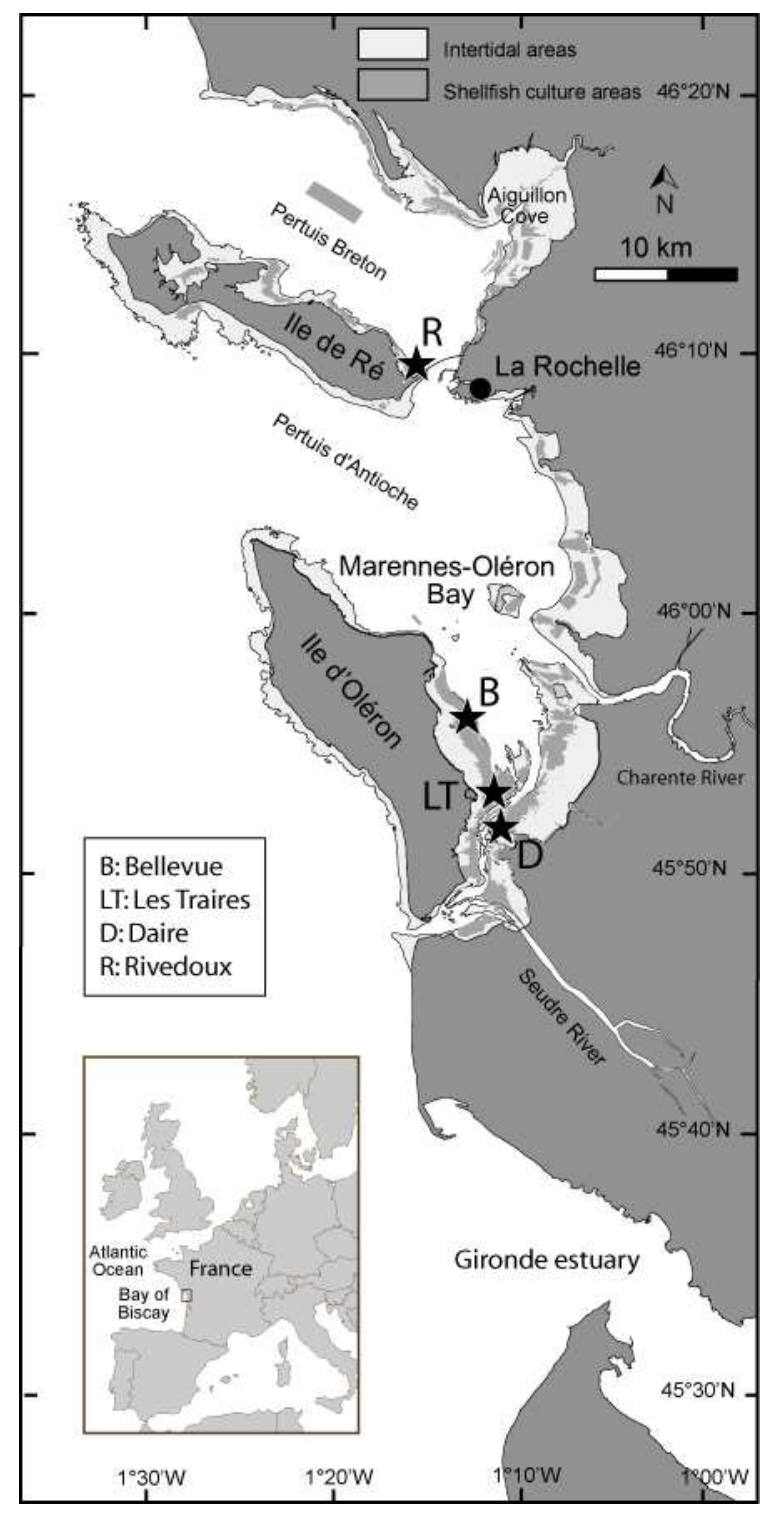




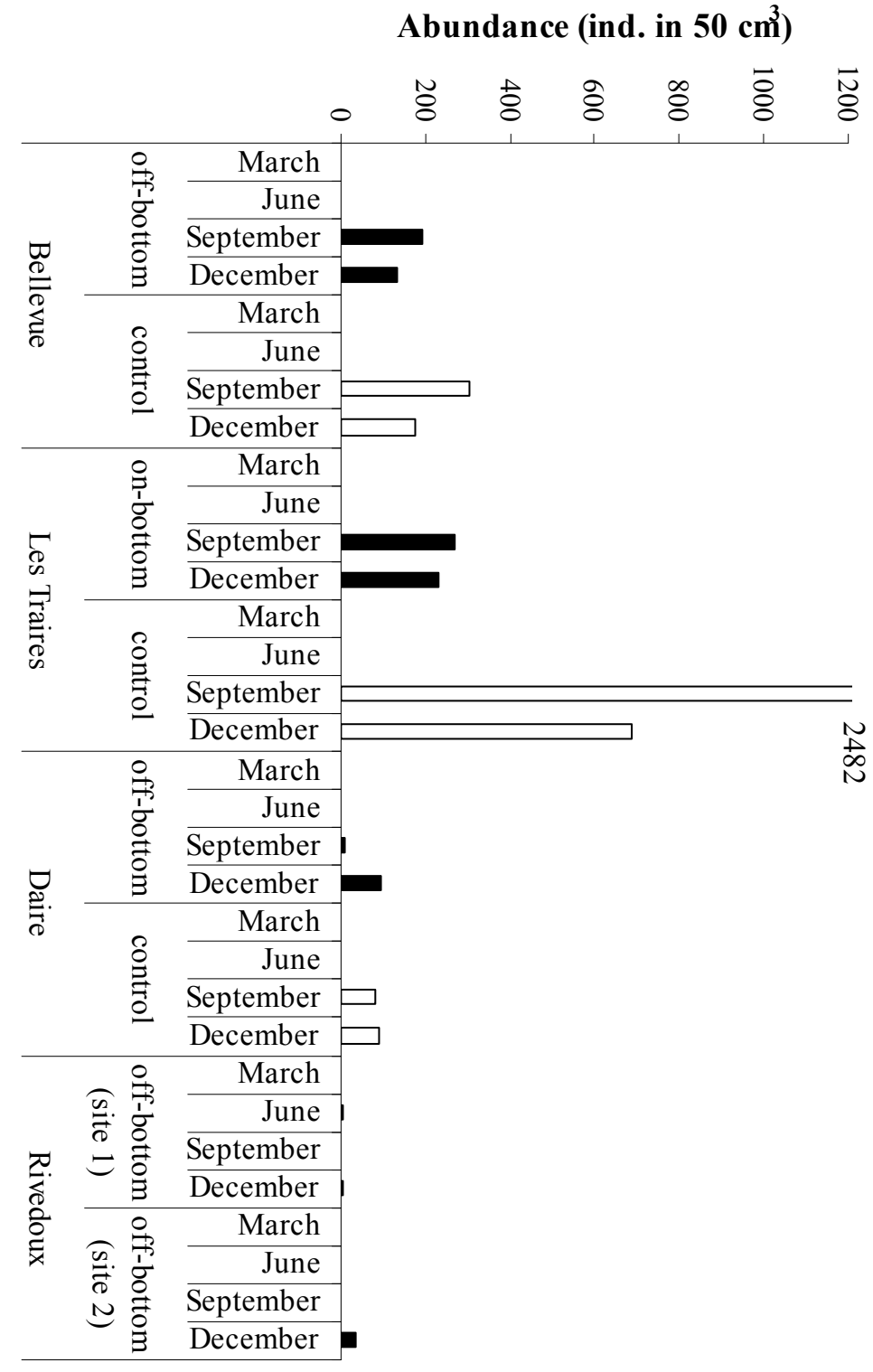


Figure 3

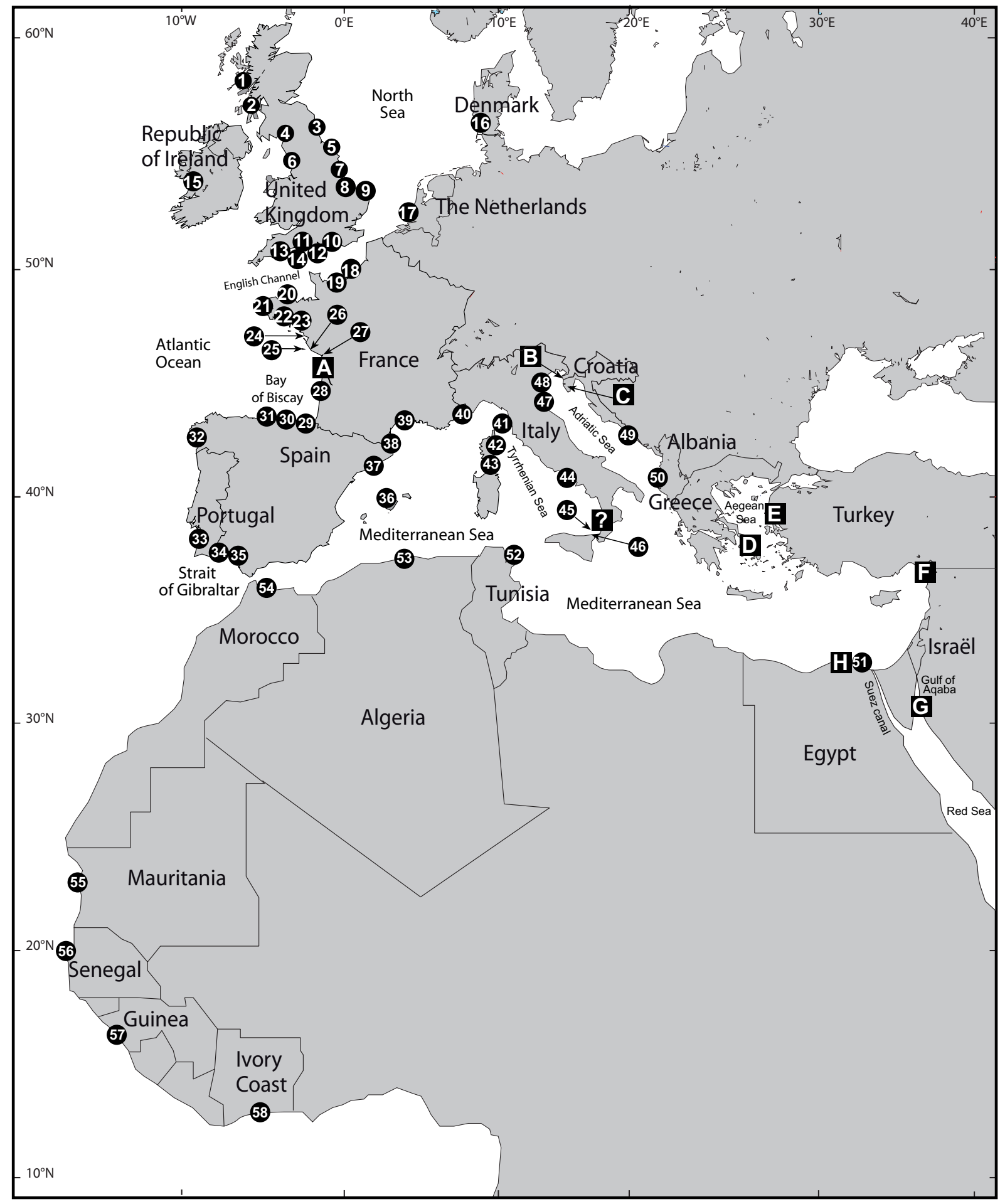


Plate caption

PLATE 1. SEM microphotographs of Quinqueloculina carinatastriata from Les Traires, France, September 2004 (scale bar: $50 \mu \mathrm{m}$ ). 1 Ventral view. 2 Dorsal view showing chambers arranged in a quinqueloculine pattern. 3 Left view showing costae running obliquely on the chambers. 4 Carinal view. 5, 6 Apertural view showing a small peristomial lip and a small tooth, hardly bifid at the tip. 
Plate 1

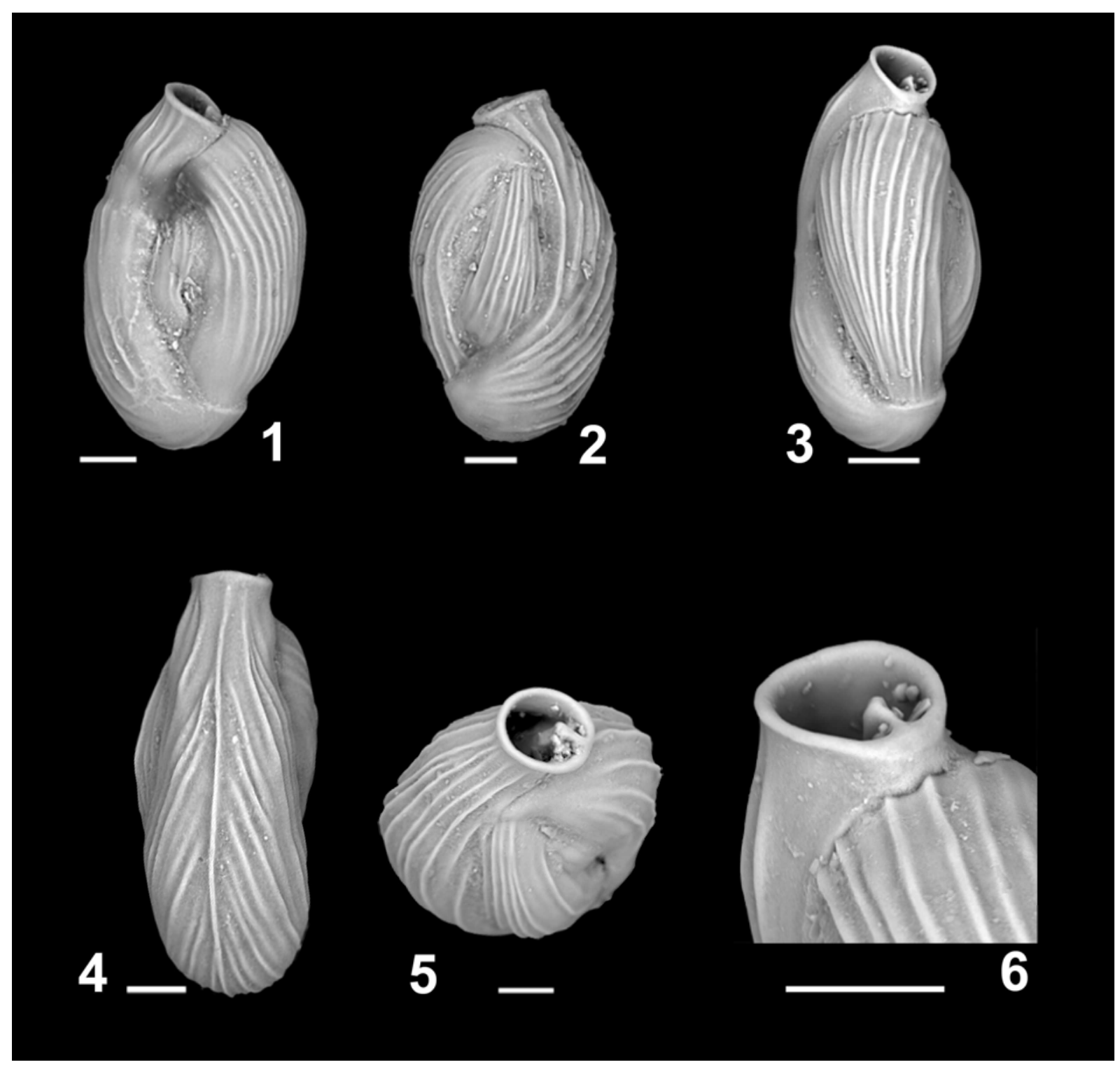


Table captions

TABLE 1. Morphological characteristics of Quinqueloculina carinatastriata (Wiesner, 1923) and Q. tasmanica Albani, 1978 as reported in previous studies (vertical descriptions on the right margin are common characters of both species).

TABLE 2. Water salinity and grain size distribution of surface sediments at Bellevue, Les Traires, Daire and Rivedoux during the sampling period. 


\section{TABLE 1}

\section{Quinqueloculina carinatastriata (Wiesner, 1923)}

Wiesner, H., 1923; Pl. 14, Figs. 190-191

The type description of Wiesner for Adelosina milletti var. carinata-striata mentions oblique costae and a carina. It does not describe the aperture, but illustrates a rounded aperture with a rim in Figure 191. The tooth is not discernible. In Figure $1 \mathrm{~b}$ of the type species $A$. milletti, the tooth is small and simple.

Zheng, S., 1979; Pl. 5, Fig. 4a-c.

Aperture with a rim and a long, simple tooth at the inner margin and a short, simple tooth at the outer margin.

Buzas, M. A., and Severin, K.P., 1982; P1. 2, Figs. 11-13.

Aperture with a rim and a small, simple tooth.

Haig, D. W., 1988; P1. 5, Figs. 6-8.

Tests laterally somewhat compressed, with a long neck, aperture with a small rim. Seems to be close to $Q$. tasmanica.

Haig, D. W., 1988; Pl. 5, Figs. 9-10.

Larger tests inflated, aperture with a rim, simple tooth.

Cimerman, F., and Langer, M. R., 1991; Pl. 20, Figs. 1-4.

Inflated chambers, periphery carinate in juveniles and truncate in adult specimens; aperture rounded. The figures show a simple tooth, inflated at its tip rather than a real T-shaped tooth as mentioned by the authors. 
Quinqueloculina tasmanica Albani, 1978

(= Quinqueloculina poeyana carinata Albani, 1974)

Albani, A. D., 1974; Pl. 1, Figs. 4-6.

The type description of Albani mentions an elongated test, chambers with a rounded periphery, the apertural end slightly extended, with a small lip and a small bifid tooth. The ornamentation consists of a series of longitudinal costae.

However, according to Haig (written communication, 2007), the holotype of $Q$. tasmanica has a laterally compressed test, an elongate neck, an oval-shaped aperture with a small simple tooth.

Baccaert, J., 1987; P1. 47, Figs. 4a, 4b.

Larger tests inflated, aperture with a rim, weak carina, simple tooth that seems slightly inflated at its end.

Baccaert, J., 1987; Pl. 47, Fig. 5a-c.

Smaller tests compressed, elongate neck, aperture with a rim, strong carina, simple tooth that seems slightly inflated at its end.

Hottinger, L., Halicz, E., and Reiss, Z., 1993; P1. 32, Figs. 1-9.

Ornamentation ranging from fine longitudinal striations to strong costae, aperture with a rim and a simple tooth slightly inflated at its end.

Yassini, I., and Jones, B. G., 1995; Fig. 217.

Aperture with a small rim and a simple tooth. 
TABLE 2

\begin{tabular}{|c|c|c|c|c|c|c|c|c|}
\hline \multirow[b]{2}{*}{ Study site } & \multicolumn{2}{|c|}{ Bellevue } & \multicolumn{2}{|c|}{ Les Traires } & \multicolumn{2}{|c|}{ Daire } & \multicolumn{2}{|c|}{ Rivedoux } \\
\hline & off-bottom & control & on-bottom & control & off-bottom & control & $\begin{array}{l}\text { off-bottom } \\
\text { (site 1) }\end{array}$ & $\begin{array}{l}\text { off-bottom } \\
\text { (site } 2 \text { ) }\end{array}$ \\
\hline & \multicolumn{8}{|c|}{ SALINITY } \\
\hline \multirow[t]{2}{*}{ Range } & \multicolumn{2}{|c|}{$31.2-32.2$} & \multicolumn{2}{|c|}{$31.1-32.1$} & \multicolumn{2}{|c|}{$30.6-32.4$} & \multicolumn{2}{|c|}{$31-32.5$} \\
\hline & \multicolumn{8}{|c|}{ GRAIN SIZE DISTRIBUTION } \\
\hline Sand & $0.6 \%$ & $15.4 \%$ & $9.3 \%$ & $11.5 \%$ & $1.8 \%$ & $17.4 \%$ & $4.2 \%$ & $7.3 \%$ \\
\hline \multirow[b]{3}{*}{ Textural oroun } & $96.1 \%$ & $81.4 \%$ & $85.8 \%$ & $85.9 \%$ & $95 \%$ & $77.6 \%$ & $92 \%$ & $89.6 \%$ \\
\hline & $3.3 \%$ & $3.2 \%$ & $4.9 \%$ & $2.6 \%$ & $3.2 \%$ & $5 \%$ & $3.8 \%$ & $3.1 \%$ \\
\hline & Mud & Sandy mud & Mud & Sandy mud & Mud & Sandy mud & Mud & Mud \\
\hline
\end{tabular}

